\title{
Pengaruh Kualitas Produk terhadap Kepuasan Pelanggan
}

\author{
Afnina \\ Jurusan Manajemen Sekolah Tinggi Ilmu Manajemen Pase Langsa \\ e-mail:afnina_nina@yahoo.co.id \\ Yulia Hastuti \\ Jurusan Manajemen Sekolah Tinggi Ilmu Manajemen Pase Langsa \\ e-mail:yulia-hastuti@yahoo.com
}

\begin{abstract}
Abstrak
Penelitian ini bertujuan untuk mengetahui dan menganalisis seberapa besar hubungan dan pengaruh antara kualitas produk terhadap kepuasan pelanggan, dengan obyek pada Toko Aneka Jaya Furniture di Langsa. Hasil-hasil yang diperoleh menunjukkan bahwa terdapat sifat keeratan hubungan yang terjadi cukup kuat dan bernilai positif antara kualitas produk dengan kepuasan pelanggan. Sedangkan besaran r-kuadrat menyatakan bahwa kualitas produk mempunyai pengaruh yang positif dan signifikan terhadap kepuasan pelanggan. Dengan demikian, hipotesis dalam penelitian ini diterima. Berdasarkan kesimpulan yang diperoleh, disarankan agar pelanggan dapat memilih produk ditawarkan yang berkualitas dan sesuai dengan kebutuhan, keinginan dan harapan sehingga benarbenar yakin untuk menggunakan produk tersebut sehingga tidak kecewa pasca pembelian.
\end{abstract}

Kata kunci: Kualitas produk, kepuasan pelanggan.

\section{PENDAHULUAN}

Seorang kosumen atau pelanggan dikatakan puas apabila ia senang dan mempunyai perilaku yang kuat untuk menggunakan atau membeli lagi secara rutin sebuah produk atau jasa. Bagaimana cara membentuk kepuasan pelanggan, tentunya harus dimulai dengan memberikan kualitas produk atau jasa yang unggul atau superior, sehingga pelanggan merasa puas dengan pengalaman mengkonsumsinya.

Kepuasan pelanggan berawal dari penilaian konsumen terhadap kualitas produk atau jasa yang diterimanya (persepsi) berdasarkan harapan yang telah terkonsep dalam pikirannya. Harapan tersebut muncul dari produk atau jasa yang telah diterima sebelumnya (pengalaman) serta berita dari mulut ke mulut yang sampai pada pelanggan. Penilaian itu akan menimbulkan kepuasan dan ketidakpuasan. Pelanggan akan merasa puas jika kualitas yang diberikan telah sesuai atau bahkan melebihi harapan mereka. Namun sebaliknya, jika kualitas produk atau jasa yang diberikan kurang ataupun berada di bawah harapan, maka pelanggan akan kecewa. Pengukuran atas tingkat kepuasan pelanggam perusahaan merupakan hal yang sangat penting, karena dengan demikian maka kinerja perusahaan dapat diukur dan dibandingkan dengan para pesaingnya. Selain itu perusahaan dapat mengetahui jika ada kekurangan atau kelemahan terhadap kualitas produk (barang atau jasa) yang ditawarkan. Sikap dan tindak lanjut adalah penting untuk menumbuhkan pelanggan yang loyal. Bila pelanggan menjadi hilang atau tidak aktif, tindakan harus diambil dalam upaya merebut kembali bisnis.

Dalam pelaksanaan pengembangan penjualan dapat disesuaikan dengan selera pelanggan, dengan harapan agar pelanggan merasa puas atas produk yang telah diberikan atau diperjualbelikan. Persaingan yang cukup 
ketat seperti sekarang ini, perusahaan dituntut untuk menawarkan produk yang berkualitas dan mempunyai nilai lebih, sehingga tampak berbeda dengan produk pesaing. Kualitas merupakan salah satu faktor yang menjadi pertimbangan konsumen sebelum membeli suatu produk. Kualitas ditentukan melalui sekumpulan kegunaan serta fungsinya, termasuk didalamnya daya tahan, ketidaktergantungan pada produk lain atau komponen lain, eksklusifitas, kenyamanan, wujud luar (warna, bentuk, pembungkusan, dan lainnya). Dengan kualitas yang bagus dan terpercaya, maka produk akan senantiasa tertanam di benak konsumen, karena konsumen bersedia membayar sejumlah uang untuk membeli produk yang berkualitas.

Penelitian ini dilakukan di Toko Aneka Jaya Furniture yang merupakan salah satu perusahaan yang bergerak di bidang penjualan furniture atau perabot rumah tangga. Saat ini pihak perusahaan secara intensif melakukan pengembangan dalam berbagai bidang seperti produk buatan dalam dan luar negeri, strategi penyesuaian harga seperti harga kredit, dan juga memberikan berbagai diskon dan hadiah lainnya demi menciptakan kepuasan bagi pelanggan, sehingga terbentuk opini dari pelanggan untuk membeli ulang terhadap produk yang ditawarkannya.

Permasalahan yang terjadi belakangan ini, pelanggan banyak yang mengadukan keluhan mereka yang diakibatkan oleh furniture yang mereka beli lebih mahal dari toko lain, ada juga yang mengatakan bahannya tidak sesuai dengan harga yang ditetapkan, banyak produk yang kurang berkualitas. Selain itu, karyawan juga mudah marah jika pelanggan banyak bertanya, produk furniture juga kurang bervariasi.

Tujuan penelitian ini adalah untuk mengetahui dan menganalisis seberapa besar hubungan dan pengaruh antara kualitas produk terhadap kepuasan pelanggan. Obyek penelitian pada Toko Aneka Jaya Furniture di Langsa. Kegunaan penelitian ini adalah agar hasil penelitian dapat dimanfaatkan sebagai bahan masukan bagi Toko Aneka Jaya Furniture di Langsa sebagai gambaran seberapa besar kualitas produk terhadap kepuasan pelanggan dalam menggunakan produk yang ditawarkan tersebut.

\section{Kualitas Produk}

Mutu atau kualitas merupakan isu yang dominan pada banyak perusahaan, bersamaan dengan waktu yang pesat, fleksibilitas dalam memenuhi permintaan konsumen (produk yang dibuat selalu sesuai dengan apa yang diminta konsumen) dan harga jual yang rendah, mutu merupakan pilihan kunci dan strategis. Menurut Tjiptono (2013), kualitas produk adalah kualitas meliputi usaha memenuhi atau melebihi harapan pelanggan; kualitas yang mencakup produk, jasa, manusia, proses, serta lingkungan; kualitas merupakan kondisi yang selalu berubah (misalnya apa yang dianggap merupakan kualitas saat ini mungkin dianggap kurang berkualitas pada masa mendatang). Kotler dan Armstrong (2013) berpendapat bahwa kemampuan sebuah produk memperagakan fungsinya, hal itu termasuk keseluruhan durabilitas, reliabilitas, ketepatan, kemudahan pengoperasian dan reparasi produk juga atribut produk lainnya.

Kualitas penting artinya dan merupakan salah satu faktor keunggulan yang kompetitf. Kedudukan kualitas menjadi sangat penting sejak persaingan pasar dunia semakin ketat. Persaingan yang ketat tersebut antara lain dipicu oleh kondisi globalisasi yang semakin cepat kemajuannya. Aliran modal, sumber daya dan produk semakin bebas menembus batas-batas antar negara. Prawirosentono (2012) menyatakan bahwa kualitas produk merupakan hal yang sangat penting untuk dijaga agar suatu industri tidak kehilangan konsumen, dan reputasi perusahan tetap terjaga dengan baik. Kualitas produk adalah keseluruhan gabungan karakteristik produk dan jasa dari aspek pemasaran, rekayasa, manufaktur, dan pemeliharaan yang sesuai dengan harapan konsumen terhadap produk dan jasa tersebut (Umar, 2013; Tjiptono \& Chandra, 2013). Bagian dari kualitas produk adalah perihal kualitas produk. Tjiptono (2013) menyatakan beberapa faktor yang sering digunakan saat mengevaluasi kepuasan konsumen terhadap suatu produk, yaitu: 
(1)kinerja (performance) berupa pemberian manfaat produk bagi konsumen yang mengkonsumsi; (2)keistimewaan tambahan (feature) produk, yaitu ciri khas yang membedakan suatu produk dengan produk pesaing sejenis; (3)keandalan (reliability) yaitu kemungkinan kecil atas suatu kegagalan pakai atau kerusakan; (4)kesesuaian dengan spesifkasi (conformance to specification) yaitu sejauh mana karakteristik desain operasi memenuhi standar-standar yang telah ditetapkan sebelumnya; (4)daya tahan (durability) yang berkaitan dengan berapa lama produk tersebut dapat terus digunakan; (5)kegunaan (serviceability) yang meliputi kecepatan, kompetensi, kenyamanan, mudah direparasi, serta penanganan keluhan yang memuaskan; (6)estetika (aestethic) yaitu daya tarik produk terhadap panca indera; dan, (7)kualitas yang dipersepsikan (perceived quality) meliputi cita rasa, reputasi produk, dan tanggung jawab perusahaan terhadap produk yang dikonsumsi oleh konsumen.

Pemenuhan kebutuhan dan keinginan konsumen tidaklah selalu semudah yang dibayangkan. Bagian dari kualitas produk adalah perihal kualitas produk. Konsumen tidak selalu mengatakan apa yang mereka inginkan dan banyak produk yang kurang berhasil karena kegagalan dalam memahami aspek-aspek yang sesungguhnya bernilai bagi pelanggan mereka seperti kualitas produk yang handal (Umar, 2013; MBSO, 2014).

\section{Kepuasan Pelanggan}

Tingkat kepuasan merupakan fungsi dari perbedaan antara kinerja yang dirasakan dengan harapan. Harapan pelanggan dapat dibentuk oleh pengalaman masa lampau, komentar dari kerabatnya serta janji akan informasi pemasar dan saingannya. Pelanggan yang puas akan setia lebih lama, kurang sensitif terhadap harga dan memberi komentar yang baik tentang perusahaan. Menurut Supranto (2013), tersenyum dan mengatakan hal-hal yang baik merupakan manifestasi atau indikator tentang suatu construct yang disebut dengan kepuasan pelanggan. Kepuasan atau ketidakpuasan pelanggan adalah respon pelanggan terhadap evaluasi ketidaksesuaian atau diskonfirmasi yang dirasakan antara harapan sebelumnya (atau norma kinerja lainnya) dan kinerja aktual produk yang dirasakan setelah pemakaian (Hendroyono, 2014; Tjiptono, 2013). Untuk dapat mengukur kepuasan pelanggan harus mengetahui definisinya secara konseptual, teoritis. Dalam kaitan itu, ada yang mendefinisikan kepuasan pelanggan sebagai hasil penilaian pelanggan terhadap apa yang diharapkannya dengan membeli dan mengkonsumsi suatu produk (Aritonang, 2013; Griffin, 2014). Harapan itu lantas dibandingkan dengan persepsinya terhadap kinerja yang diterimanya dengan mengkonsumsi produk itu. Dengan demikian, untuk menciptakan kepuasan konsumen, perusahaan harus bisa membuat suatu sistem untuk meraih pelanggan yang lebih banyak dan kemampuan untuk mempertahankannya. Kepuasan pelanggan sering ditentukan oleh kualitas produk atau jasa yang ditawarkan.

Kepuasan pelanggan diterangkan di dalam model "disconfirmation of expectation" sebagai perasaan puas yang wujud apabila pelanggan membandingkan antara tanggapan prestasi keluaran dengan harapan mereka terhadap prestasi keluaran tersebut (Fajrianti \& Farrah, 2005; Suryani, 2013). Pelanggan akan berpuas hati apabila tanggapan sama atau melebihi harapan mereka. Tjiptono (2013) mengidentifikasikan empat metode untuk mengukur kepuasan pelanggan, yaitu: (1)Sistem Keluhan dan Saran; (2)Ghost Shopping (Mystery Shopping); (3)Lost Costumer Analysis; serta, (4)Survei Kepuasan Pelanggan (terdiri dari: directly reported satisfaction, derived satisfaction, problem analysis, dan important performance analysis).

Kotler (2013) juga mengemukakan beberapa metode yang dapat digunakan untuk mengukur kepuasan pelanggan. Metode pertama adalah sistem pengaduan, yang memberikan kesempatan kepada pelanggan untuk memberikan saran, keluhan dan bentuk ketidakpuasan lainnya dengan menyediakan kotak saran. Metode kedua adalah survey pelanggan, seperti melalui surat pos, telepon, atau wawancara secara langsung. Metode ketiga adalah panel pelanggan, dimana 
perusahaan mengundang pelanggan yang setia terhadap produk dan mengundang pelanggan yang telah berhenti membeli atau telah pindah menjadi pelanggan perusahaan lain.

Menurut Lupiyoadi (2013), dalam menentukan tingkat kepuasan, terdapat lima faktor utama yang harus diperhatikan oleh perusahaan. Faktor pertama adalah kualitas produk, dimana pelanggan akan merasa puas bila hasil evaluasi mereka menunjukkan bahwa produk yang mereka gunakan berkualitas. Faktor kedua adalah kualitas pelayanan, dimana terutama untuk industri jasa, pelanggan akan merasa puas bila mereka mendapatkan pelayanan yang baik atau yang sesuai dengan yang diharapkan. Faktor ketiga adalah emosional, dimana pelanggan akan merasa bangga dan mendapatkan keyakinan bahwa orang lain akan kagum terhadap dia bila menggunakan produk dengan merek tertentu yang cenderung mempunyai tingkat kepuasan lebih tinggi. Dalam hal ini, kepuasan yang diperoleh bukan karena kualitas dari produk, tetapi nilai sosial atau self esteem yang membuat pelanggan menjadi puas terhadap merek tertentu. Faktor keempat adalah harga, dimana produk yang memiliki kualitas sama tetapi menetapkan harga yang relatif murah akan memberikan nilai yang lebih tinggi kepada pelanggannya. Faktor kelima adalah biaya, yaitu situasi dimana pelanggan tidak perlu mengeluarkan biaya tambahan atau tidak perlu membuang waktu untuk mendapatkan suatu produk atau jasa cenderung puas terhadap produk atau jasa itu.

Berdasarkan beberapa pendapat itu, maka pada dasarnya kepuasan pelanggan merupakan hasil evaluasi purnabeli dan alternatif yang dipilih setidaknya sama atau melebihi harapan pelanggan.

\section{Kerangka Pikir dan Hipotesis}

Demi menyenangkan pelanggan, suatu perusahaan atau organisasi akan terus berusaha sekeras mungkin. Ada beberapa pelanggan menunjukkan ketidakpuasan yang tinggi meskipun sebenarnya mereka puas. Menurut Umar (2013), beberapa faktor utama yang mempengaruhi kepuasan pelanggan adalah mutu produk dan pelayanannya, serta pelayanan setelah penjualan. Menurut Tjiptono (2013), salah satu faktor yang mempengaruhi kepuasan pelanggan adalah fitur produk dan jasa. Dalam hal ini, kepuasan pelanggan terhadap produk atau jasa secara signifikan dipengaruhi oleh hasil evaluasi pelanggan terhadap fitur produk atau jasa.

Dalam melakukan studi kepuasan, banyak perusahaan menggunakan kelompok fokus untuk menentukan fitur dan atribut penting dari jasa dan kemudian mengukur persepsi pelanggan terhadap fitur itu. Pelanggan jasa akan membuat trade-off antara fitur jasa yang berbeda (misalnya, tingkat harga dengan kualitas, atau dengan keramahan karyawan), tergantung pada tipe jasa yang dievaluasi dan tingkat kekritisan jasa.

Menurut Lupiyoadi (2013), salah satu faktor utama yang harus diperhatikan oleh perusahaan adalah kualitas produk. Pelanggan akan merasa puas bila hasil evaluasi mereka menunjukkan bahwa produk yang mereka gunakan berkualitas. Faktor harga produk juga berperan utama, dimana produk yang mempunyai kualitas sama tetapi menetapkan harga yang relatif murah akan memberikan nilai yang lebih tinggi kepada pelanggannya.

Berdasarkan pendapat para ahli tersebut, ukuran kepuasan yang dirasakan konsumen saat menggunakan suatu produk ini relatif dipengaruhi kuat oleh kualitas produk. Dengan demikian, dihipotesiskan dalam penelitian ini bahwa kualitas produk berpengaruh signifikan terhadap kepuasan pelanggan.

\section{METODE PENELITIAN}

Teknik pengumpulan data yang digunakan dalam penelitian ini terdiri dari observasi, interview dan kuesioner. Observasi merupakan penelitian yang dilakukan untuk mengumpulkan data dan informasi dengan melakukan pengamatan langsung dan melihat keadaan yang sesungguhnya pada objek yang diteliti, yaitu pelanggan pada Toko Aneka Jaya Furniture di Langsa.

Interview merupakan pengumpulan data yang dilakukan dengan cara wawancara dan tatap muka langsung dengan responden 
sebagai pelanggan pada Toko Aneka Jaya Furniture di Langsa. Kuesioner: merupakan pernyataan dalam bentuk angket yang dibagikan kepada para pelanggan pada Toko Aneka Jaya Furniture di Langsa yang terpilih menjadi responden.

\section{Penentuan Sampel}

Sampel diambil menggunakan teknik purposive sampling, berarti sampel atas dasar persyaratan tertentu (Istijanto, 2014). Dalam penelitian ini, sampel dipersyaratkan memiliki pengalaman cukup dalam menggunakan produk furniture pada Toko Aneka Jaya Furniture di Langsa, yaitu bahwa sampel sudah pernah membeli dan menggunakan sendiri produk furniture tersebut dalam setahun terakhir dan telah membeli minimal sebanyak tiga produk furniture pada Toko Aneka Jaya Furniture di Langsa. Akibatnya tidak semua pelanggan pada Toko Aneka Jaya Furniture di Langsa memiliki peluang yang sama untuk terpilih sebagai sampel (nonprobability).

Penentuan banyaknya jumlah sampel mengacu pada pendapat Suparmoko (2013) bahwa sebaiknya ukuran sampel terkecil adalah 30 elemen. Berdasarkan teori tersebut dan mengingat keterbatasan jumlah sampel yang diperoleh di lapangan, maka penentuan jumlah sampel dihentikan setelah responden mencapai 40 orang. Jadi penentuan jumlah sampel sebanyak 40 orang dalam penelitian ini sudah mencukupi syarat yang berlaku dalam teori minimal sampel untuk kebutuhan generalisasi.

\section{Metode Regresi Linier Berganda}

Metode analisis data yang digunakan untuk melihat pengaruh kualitas produk terhadap kepuasan pelanggan pada Toko Aneka Jaya Furniture di Langsa adalah analisis regresi linier berganda (Supranto, 2013) dengan formula:

$$
\mathrm{Y}=\mathrm{b}_{0}+\mathrm{b}_{1} \mathrm{x}_{1}+\varepsilon
$$

dimana $\mathrm{Y}$ adalah kepuasan pelanggan; $\mathrm{b}_{0}$ adalah nilai konstanta; $b_{1}$ adalah koefisien regresi; $\mathrm{x}_{1}$ adalah kualitas produk, dan $\varepsilon$ adalah error term.
Variabel terikat adalah kepuasan pelanggan, yang diukur dengan menggunakan indikator-indikator yang meliputi kualitas produk, kualitas pelayanan, emosional, harga, dan biaya (Lupiyoadi, 2013; Siregar, 2014). Variabel bebas adalah kualitas produk, yang diukur menggunakan indikator-indikator kinerja, keistimewaan, keandalan, kesesuaian, daya tahan, kegunaan, estetika, serta kualitas yang dipersepsikan (Umar, 2013).

\section{Pengujian Hipotesis}

Proses selanjutnya adalah melakukan pembuktian hipotesis. Dikarenakan hanya terdapat satu variabel bebas saja yang mempengaruhi satu variabel terikat, maka uji hipotesis dilakukan menggunakan teknik analisis uji $\mathrm{F}(F$-test).

Pengujian hipotesis dengan Uji $F$ digunakan untuk mengetahui apakah variabel bebas berpengaruh secara signifikan atau tidak kepada variabel terikat. Kriteria yang digunakan adalah membandingkan nilai Sig. F terhadap $\alpha(0,05)$. Apabila nilai Sig. $\mathrm{F}<\alpha$ maka Ho ditolak dan $\mathrm{Ha}$ diterima, yang berarti variabel bebas berpengaruh signifikan terhadap variabel terikat. Sebaliknya, apabila nilai Sig. $\mathrm{F}>\alpha$ maka Ho diterima dan $\mathrm{Ha}$ ditolak, yang berarti bahwa variabel bebas berpengaruh tidak signifikan terhadap variabel terikat (Umar, 2013; Supranto, 2013).

\section{HASIL ANALISIS}

\section{Analisis Pendapat Reponden tentang Kualitas Produk}

Salah satu nilai utama yang diharapkan pelanggan dari produsen adalah kualitas produk. Kualitas merupakan suatu kondisi dinamis yang berhubungan dengan produk, jasa, manusia, proses dan lingkungan yang memenuhi atau melebihi harapan. Seberapa besar kualitas yang diberikan berhubungan dengan produk barang beserta faktor-faktor pendukungnya dalam memenuhi harapan penggunanya. Dapat diartikan bahwa semakin memenuhi harapan konsumen, produk itu semakin berkualitas. Kualitas produk adalah kemampuan barang memberikan hasil/kinerja yang sesuai ataupun melebihi apa yang diinginkan pelanggan. 
Tabel 1

Pendapat Responden mengenai Kualitas Produk pada Toko Aneka Jaya Furniture

\begin{tabular}{clc}
\hline No & \multicolumn{1}{c}{ Pernyataan } & Nilai Mean \\
\hline 1 & $\begin{array}{l}\text { Saya puas dengan kinerja produk yang dijual pada Toko Aneka Jaya } \\
\text { Furniture di Langsa. }\end{array}$ & 3,40 \\
\hline 2 & $\begin{array}{l}\text { Berbagai produk yang dijual oleh Toko Aneka Jaya Furniture di Langsa } \\
\text { lebih unggul dari pesaing. }\end{array}$ & 3,48 \\
\hline 3 & $\begin{array}{l}\text { Produk yang dijual pada Toko Aneka Jaya Furniture di Langsa mempunyai } \\
\text { daya tahan yang handal. }\end{array}$ & 3,13 \\
\hline 4 & $\begin{array}{l}\text { Produk yang dijual pada Toko Aneka Jaya Furniture di Langsa telah sesuai } \\
\text { dengan harapan saya. }\end{array}$ & 3,28 \\
\hline 5 & $\begin{array}{l}\text { Setelah menggunakan produk dari Toko Aneka Jaya Furniture di Langsa, } \\
\text { saya merasa menjadi lebih senang memandangi suasana di rumah saya. }\end{array}$ & 3,53 \\
\hline 6 & $\begin{array}{l}\text { Dengan menggunakan produk yang dibeli dari Toko Aneka Jaya Furniture di } \\
\text { Langsa membuat saya lebih dihargai oleh masyarakat. }\end{array}$ & 3,45 \\
\hline 7 & $\begin{array}{l}\text { Produk yang saya beli pada Toko Aneka Jaya Furniture di Langsa } \\
\text { mempunyai estetika (daya tarik) tersendiri. }\end{array}$ & 3,65 \\
\hline 8 & $\begin{array}{l}\text { Kualitas berbagai produk yang dijual oleh Toko Aneka Jaya Furniture di } \\
\text { Langsa telah sesuai dengan apa yang saya bayangkan. }\end{array}$ & 3,68 \\
\hline \multicolumn{4}{c}{ Rata-Rata Keseluruhan } \\
\hline
\end{tabular}

Sumber: Data primer (diolah), Tahun 2017.

Berdasarkan hasil analisis deskriptif, pendapat para responen mengenai kualitas produk pada Toko Aneka Jaya Furniture dirangkum dalam Tabel 1.

Berdasarkan Tabel 1, nilai mean untuk pernyataan 1 mengenai kualitas produk diperoleh sebesar 3,40 atau pada skala 3 (cukup setuju); yang berarti bahwa para responden cukup puas dengan kinerja produk yang dijual pada Toko Aneka Jaya Furniture di Langsa. Nilai mean untuk pernyataan 2 diperoleh sebesar 3,48 atau pada skala 3 (cukup setuju); yang berarti para responden merasa cukup setuju bahwa berbagai produk yang dijual oleh Toko Aneka Jaya Furniture di Langsa lebih unggul dari pesaing. Nilai mean untuk pernyataan 3 diperoleh sebesar 3,13 atau pada skala 3 (cukup setuju); yang berarti para responden merasa cukup setuju bahwa produk yang dijual pada Toko Aneka Jaya Furniture di Langsa mempunyai daya tahan yang handal.

Nilai mean untuk pernyataan 4 diperoleh sebesar 3,28 atau pada skala 3 (cukup setuju); yang berarti para responden merasa cukup setuju bahwa produk yang dijual pada Toko Aneka Jaya Furniture di Langsa telah sesuai dengan harapan mereka. Nilai mean untuk pernyataan 5 diperoleh sebesar 3,53 atau pada skala 3 (cukup setuju); yang berarti para responden merasa cukup setuju bahwa setelah menggunakan produk dari Toko Aneka Jaya Furniture di Langsa, mereka merasa menjadi lebih senang saat memandangi suasana di rumahnya.

Nilai mean untuk pernyataan 6 diperoleh sebesar 3,45 atau pada skala 3 (cukup setuju); yang berarti para responden merasa cukup setuju bahwa dengan menggunakan produk yang dibeli dari Toko Aneka Jaya Furniture di Langsa membuat mereka lebih dihargai oleh masyarakat. Nilai mean untuk pernyataan 7 diperoleh sebesar 3,65 atau pada skala 3 (cukup setuju); yang berarti para responden merasa cukup setuju bahwa produk yang mereka beli pada Toko Aneka Jaya Furniture di Langsa mempunyai estetika (daya tarik) tersendiri. Nilai mean 
untuk pernyataan 8 diperoleh sebesar 3,68 atau pada skala 3 (cukup setuju); yang berarti para responden merasa cukup setuju bahwa kualitas berbagai produk yang dijual oleh Toko Aneka Jaya Furniture di Langsa telah sesuai dengan apa yang mereka bayangkan.

Secara keseluruhan, nilai mean pada variabel kualitas produk diperoleh rata-rata sebesar 3,45, atau pada skala 3 (cukup setuju). Ini bermakna bahwa kualitas produk yang ditawarkan oleh Toko Aneka Jaya Furniture di Langsa telah memiliki kualitas produk dalam kategori cukup baik atau cukup berkualitas.

\section{Analisis Pendapat Reponden tentang Kepuasan Pelanggan}

Kepuasan pelanggan merupakan suatu tingkatan di mana kebutuhan, keinginan dan harapan dari pelanggan dapat terpenuhi yang akan mengakibatkan terjadinya pembelian ulang atau kesetiaan yang berlanjut. Produk berkualitas mempunyai peranan penting untuk membentuk kepuasan pelanggan. Semakin berkualitas produk yang diberikan, maka kepuasan yang dirasakan oleh pelanggan semakin tinggi. Bila kepuasan pelanggan semakin tinggi, maka dapat menimbulkan keuntungan bagi perusahaan itu. Perusahaan dapat mengetahui kepuasan dari para pelanggannya melalui umpan balik yang diberikan oleh pelanggan kepada perusahaan sehingga dapat menjadi masukan untuk keperluan pengembangan dan implementasi serta peningkatan kepuasan pelanggan. Dari sini dapat diketahui pada saat pelanggan komplain. Ini adalah peluang bagi perusahaan untuk dapat mengetahui kinerjanya.

Analisis deskriptif memperlihatkan pendapat para responden mengenai kepuasan mereka melakukan pembelian pada Toko Aneka Jaya Furniture dapat dirangkum dalam Tabel 2. Berdasarkan tabel tersebut, nilai mean untuk pernyataan 1 mengenai kepuasan pelanggan diperoleh sebesar 3,80 atau pada skala 3 (cukup setuju); yang berarti bahwa para responden cukup puas menggunakan produk yang dijual oleh Toko Aneka Jaya Furniture di Langsa karena kualitas produk ini telah mereka buktikan sendiri.
Nilai mean untuk pernyataan 2 diperoleh sebesar 3,43 atau pada skala 3 (cukup setuju); yang berarti para responden merasa cukup setuju kualitas pelayanan yang diberikan telah sesuai dengan harapan mereka. Nilai mean untuk pernyataan 3 diperoleh sebesar 3,50 atau pada skala 3 (cukup setuju); yang berarti para responden merasa cukup setuju bahwa mereka merasa bangga menggunakan produk yang dijual oleh Toko Aneka Jaya Furniture di Langsa. Nilai mean untuk pernyataan 4 diperoleh sebesar 3,25 , atau pada skala 3 (cukup setuju); yang berarti para responden merasa cukup setuju bahwa harga berbagai produk yang dijual oleh Toko Aneka Jaya Furniture di Langsa sesuai dengan kualitas yang ditawarkan.

Nilai mean untuk pernyataan 5 diperoleh sebesar 3,63 atau pada skala 3 (cukup setuju); yang berarti para responden merasa cukup setuju bahwa dalam mendapatkan berbagai produk yang dijual oleh Toko Aneka Jaya Furniture di Langsa mereka tidak perlu mengeluarkan biaya yang besar karena tersedia harga diskon bahkan boleh kredit dengan harga terjangkau.

Secara keseluruhan, nilai mean pada variabel kepuasan pelanggan diperoleh ratarata sebesar 3,52 atau pada skala 3 (cukup setuju). Ini bermakna bahwa pelanggan telah merasakan cukup puas dalam menggunakan produk yang telah dibeli oleh mereka pada Toko Aneka Jaya Furniture di Langsa.

\section{Analisis Regresi Linier Sederhana}

Kepuasan pelanggan sebagai variabel terikat (Y) sangat tergantung pada variabel bebas yang mempengaruhinya, yaitu kualitas produk (X). Untuk mengukur seberapa besar pengaruh variabel bebas tersebut terhadap variabel terikat digunakan perhitungan regresi linier sederhana. Hasil olah data dengan menggunakan program SPSS dirangkum dalam Tabel 3.

Berdasarkan hasil olah data yang dirangkum dalam Tabel 3, dapat dibentuk suatu persamaan regresi linier sederhana untuk penelitian ini sebagai berikut:

$$
\mathrm{Y}=8,683+0,323 \mathrm{X}
$$


Tabel 2

Pendapat Responden mengenai Kepuasan Pelanggan pada Toko Aneka Jaya Furniture

\begin{tabular}{clc}
\hline No & \multicolumn{1}{c}{ Pernyataan } & Nilai Mean \\
\hline 1 & $\begin{array}{l}\text { Saya puas menggunakan produk yang dijual oleh Toko Aneka Jaya Furniture } \\
\text { di Langsa karena kualitas produk ini telah saya buktikan sendiri. }\end{array}$ & 3,80 \\
\hline 2 & Kualitas pelayanan yang diberikan telah sesuai dengan harapan saya. & 3,43 \\
\hline 3 & $\begin{array}{l}\text { Saya merasa bangga menggunakan produk yang dijual oleh Toko Aneka Jaya } \\
\text { Furniture di Langsa. }\end{array}$ & 3,50 \\
\hline 4 & $\begin{array}{l}\text { Harga berbagai produk yang dijual oleh Toko Aneka Jaya Furniture di } \\
\text { Langsa sesuai dengan kualitas yang ditawarkan. }\end{array}$ & 3,25 \\
\hline 5 & $\begin{array}{l}\text { Dalam mendapatkan berbagai produk yang dijual oleh Toko Aneka Jaya } \\
\text { Furniture di Langsa saya tidak perlu mengeluarkan biaya yang besar karena } \\
\text { tersedia harga diskon bahkan boleh kredit dengan harga terjangkau. }\end{array}$ & 3,63 \\
\hline & \multicolumn{1}{c}{ Rata-Rata Keseluruhan } \\
\hline
\end{tabular}

Sumber: Data primer (diolah), Tahun 2017.

Tabel 3

Hasil Analisis Regresi Linier Sederhana

\begin{tabular}{lccc}
\hline \multicolumn{1}{c}{ Variabel } & B & t-hitung & Sig. t \\
\hline Konstanta & 8.683 & 3,788 & 0,001 \\
Kualitas Produk & 0,323 & 3,971 & 0,000 \\
\hline R & 0,542 & & \\
R $^{2}$ & 0,293 & & \\
F-hitung & 15,770 & & \\
Sig. F & 0,000 & & \\
\hline
\end{tabular}

Sumber: Data primer (diolah), Tahun 2017.

Tabel 3 menunjukkan nilai koefisien regresi variabel kualitas produk sebesar 0,323. Angka tersebut menyatakan bahwa kualitas produk memiliki pengaruh yang bersifat positif terhadap kepuasan pelanggan. Apabila perusahaan mampu meningkatkan kualitas produk yang ditawarkannya, maka kepuasan pelanggan juga akan mengalami peningkatan. Sebaliknya, bila perusahaan malah mengalami penurunan kualitas produk yang ditawarkan, maka kepuasan pelanggan juga mengalami penurunan.

Selain itu, Tabel 3 menjelaskan nilai koefisien korelasi (R) sebesar 0,542, yang berarti keeratan hubungan antara variabel bebas (kualitas produk) dengan variabel terikat (kepuasan pelanggan) relatif cukup kuat. Hubungan tersebut dikatakan cukup kuat karena nilai koefisien korelasi $(R)$ lebih dari 0,5 atau mendekati 1 .

Berikutnya, Tabel 3 menyatakan nilai koefisien determinasi $\left(\mathrm{R}^{2}\right)$ sebesar 0,293. Hasil ini menunjukkan bahwa kualitas produk yang diteliti dalam penelitian ini memiliki kontribusi sebesar 29,3\% untuk menjelaskan perubahan-perubahan yang terjadi dalam kepuasan pelanggan; sisanya sebesar $70,7 \%$ dipengaruhi oleh variabel-variabel lain yang tidak dianalisis dalam model penelitian ini. Variabel-variabel lain tersebut antara lain harga, harga pesaing, kualitas pelayanan, dan lain sebagainya.

\section{Hasil Uji Hipotesis}

Tabel 3 menunjukkan hasil uji menggunakan uji $\mathrm{F}$ ( $F$-test) memperoleh nilai Sig. F sebesar 0,000. Karena nilai Sig. $\mathrm{F}<\alpha$ 
$(0,005)$ menyatakan bahwa pengaruh kualitas produk terhadap kepuasan pelanggan terbukti signifikan.

Dengan demikian, bila dihubungkan dengan hasil regresi sederhana, hipotesis bahwa kualitas produk memiliki pengaruh yang positif dan signifikan terhadap kepuasan pelanggan bisa diterima atau dibuktikan.

\section{KESIMPULAN}

Hasil analisis deskriptif menunjukkan bahwa mayoritas responden berpendapat bahwa kualitas produk yang ditawarkan oleh Toko Aneka Jaya Furniture di Langsa telah memiliki kualitas produk dalam kategori cukup baik atau cukup berkualitas. Selain itu, mayoritas responden berpendapat bahwa mereka telah merasakan cukup puas dalam menggunakan produk yang telah dibeli oleh mereka pada Toko Aneka Jaya Furniture di Langsa.

Hasil analisis statistik menunjukkan bahwa terdapat sifat keeratan hubungan yang cukup kuat dan bernilai positif antara kualitas produk dengan kepuasan pelanggan. Selain itu, juga diperoleh bahwa kualitas produk mempunyai pengaruh signifikan terhadap kepuasan pelanggan.

Berdasarkan hasil-hasil penelitian yang diperoleh maka disarankan agar Toko Aneka Jaya Furniture di Langsa terus berupaya mempertahankan dan meningkatkan kepuasan pelanggannya dengan cara mempercepat dan mempermudah proses pembelian khususnya secara kredit. Toko tersebut juga sebaiknya berupaya terus mempertahankan dan meningkatkan kepuasan pelanggannya seperti memberikan hadiah atau potongan harga bagi pelanggan atau pelanggan yang sudah memiliki tingkat pembelian di atas rentang tertentu, serta bersedia menerima komplain dari pelanggan sehingga dapat memperbaiki dan meningkatkan layanan guna memberikan kepuasan kepada pelanggannya. Selain itu, diharapkan pelanggan dapat memilih produk yang ditawarkan Toko Aneka Jaya Furniture di Langsa yang berkualitas dan sesuai dengan kebutuhan, keinginan dan harapan sehingga benar-benar yakin untuk menggunakan produk tersebut sehingga tidak kecewa pasca pembelian.

\section{DAFTAR PUSTAKA}

Aritonang, L.R. 2013. Kepuasan Pelanggan: Pengukuran dan Penganalisisan dengan SPSS. Jakarta: PT. Gramedia Pustaka Utama.

Fajrianthi dan Farrah, Z. 2005. Strategi Perluasan Merek dan Loyalitas Konsumen. INSAN.Vol. 7, No. 3, hal. 276-288.

Griffin, J. 2014. Customer Loyalty: Menumbuhkan \&Mempertahankan Kesetiaan Pelanggan. Jakarta: Penerbit Erlangga.

Hendroyono, A. 2012. Mutu Pelayanan Kesehatan dan Service Recovery. www.lrc.kesehatan.net/upload/mutu $\% 20$ pelayanan.pdf-mirip. Diunduh tanggal 10 Mei 2017.

Istijanto. 2014. Riset Pemasaran. Yogyakarta: BPFE.

Kotler, P. 2013. Manajemen Pemasaran: Prinsip dan Kasus. Jakarta: PT. Prenhalindo.

Management Business Sources Online. 2014. Loyalitas Pelanggan, Pemahaman Loyalitas Pelanggan. http:/hilman 2004materials.wordpress.com/2013/04 /12/loyalitas-pelanggan. Diunduh tanggal 10 Mei 2017.

Setiadi, N.J. 2013. Perilaku Konsumen, Konsep dan Implikasi untuk Strategi dan Penelitian Pemasaran. Jakarta: Kencana Prenada Media Group.

Siregar S. 2014. Metode Penelitian Kuantitatif dilengkapi dengan Perbandingan Perhitungan Manual dan SPSS. Bandung: Kencana.

Suparmoko. M. 2013. Metode Penelitian Praktis untuk Ilmu-ilmu Sosial, Ekonomi dan Bisnis. Yogyakarta: BPFE.

Supranto, J. 2013. Pengukuran Tingkat Kepuasan Pelanggan untuk 
Menaikkan Pangsa Pasar. Jakarta: Rineka Cipta.

Suryani, T. 2013. Perilaku Konsumen, Implikasi pada Strategi Pemasaran. Yogyakarta: Graha Ilmu.

Tjiptono, F. 2013. Manajemen Jasa. Yogyakarta: ANDI.
Tjiptono, F. dan Chandra, G. 2013. Service, Quality \& Satisfaction. Yogyakarta: ANDI.

Umar, H. 2013. Studi Kelayakan Bisnis: Teknik Menganalisa Kelayakan Rencana Bisnis secara Komprehensif. Jakarta: PT. Gramedia Pustaka Utama. 